\title{
Investments in the cryptocurrency market or the commodity exchange. Which is more efficient?
}

\section{Sylwester Kozak}

\author{
Warsaw University \\ of Life Sciences \\ E-mail: sylwester_kozak@sggw.pl \\ ORCID: 0000-0001-9485-6704
}

\section{Seweryn Gajdek}

Warsaw University of Life Sciences

E-mail: seweryn.gajdek@poczta.fm ORCID: 0000-0001-5199-6758

\begin{abstract}
Cryptocurrencies have become an essential element of the global financial system, and in recent years also a frequent investment tool. The aim of the study is to check whether investments in cryptocurrencies are more effective than in commodities on commodity exchanges. The study was conducted based on the daily quotations of the analyzed instruments in 2011-2020. The investment efficiency level was estimated using Sharpe's and Sortino's indicators. The research results showed that, on average, over the entire period under study, investments in cryptocurrencies were burdened with the highest risk, but at the same time achieved the highest daily rates of return. As a result, they were much more effective investment tools than gold, silver and WTI. The advantage of cryptocurrencies could be due to the long-term persistence of ultra-low interest rates and the reduced attractiveness of investment in debt securities. Bitcoin and etherum with the largest shares in cryptocurrency market capitalization have proven to be the most effective investment tools.
\end{abstract}

Keywords: cryptocurrencies, investments, commodity exchanges, investment efficiency

\section{Introduction}

The dynamic development of the cryptocurrency market makes it more and more popular not only due to the unique technology and range of usability that supports it, but also due to its growing investment opportunities. However, the opinions of regulators and academics on this matter are strongly divided. On the one hand, supervisory offices send warning signals, especially to private individuals, against expectations to obtain quick extraordinary profits, as well as against creating a speculative bubble on cryptocurrencies (UKNF, 2021). On the other hand, many people consider BTC and other cryptocurrencies as effective tools for long-term storing value.
Publication financed by:

Małopolska School

of Economics in Tarnów

Correspondence to:

Sylwester Kozak

Szkoła Główna Gospodarstwa

Wiejskiego w Warszawie,

ul. Nowoursynowska 166

02-787 Warszawa

E-mail: sylwester_kozak@sggw.pl 
In many cases, treating cryptocurrencies only as a speculative tool is not fully justified, as it ignores many positive functionalities of cryptocurrencies, including in trade or international fund transfers. It should be emphasized that cryptocurrencies provide an important contribution to the development of electronic money technology, widely accepted and implemented by central banks. However, the cryptocurrency system clearly differs from the current vision of the financial system. The decentralization of the functioning of money, the lack of a hierarchical structure, as well as the limited and finite supply of coins should be the subject of careful study. Another problem which requires a deep analysis is the efficiency of investments in cryptocurrencies. The rationale for this is the dynamically growing investment activities of participants of the cryptocurrency market.

The aim of the article is to determine and compare the efficiency level of investments in a selected group of cryptocurrencies (bitcoin-BTC, litecoin-LTC, and etherum-ETH) with the efficiency of investments in the commodities (gold, silver, WTI crude oil [hereinafter WTI]) in 2011-2020. The rationale for choosing these cryptocurrencies was their high capitalization and longest presence on the market. Gold, silver and WTI were adopted as instruments representing the commodity exchange. Besides economic use, the analyzed commodities often serve as investment vehicles. Additionally, their international character makes them similar to cryptocurrencies. The choice of the analyzed period is related to, inter alia, the date when BTC started operating on the market. The data used in the study comes from cryptocurrency and commodity quotes published by the Thomson Reuters agency (Reuters. com, 2021). Due to the significant volatility of the quotations of the analyzed instruments, the level of investment efficiency is estimated using the Sharpe and Sortino ratios, taking into account the daily logarithmic rates of return and the standard deviation and semi-standard deviation of daily rates of return.

The research hypothesized that the efficiency of investments in cryptocurrencies, measured by the Sharpe and Sortino ratios, is higher than the efficiency of investments in typical commodity exchange instruments.

The rest of the article is structured as follows. The next sections of the paper present: the literature review, the assessment of the global macroeconomic situation, research methods, as well as research results and discussion of them. The whole is summarized in the conclusions.

\section{Literature review}

The subject of assessing the efficiency of investments in cryptocurrencies is not so frequently analyzed in the economic literature. The problem of risk that arises when investing in cryptocurrencies is analyzed relatively often, as well as the ability of cryptocurrencies to diversify investment portfolios consisting of both shares and commodities. Hung, Ly, Lu, Hoang and Wong (2021) compared the efficiency of diversification of investment portfolios using gold and BTC in 2010-2020. They found that gold has a greater than BTC ability to diversify risk in investment portfolios. However, the portfolios containing BTC brought higher investment returns, although they were characterized by greater volatility of daily rates of return. The survey results therefore suggest that investors with higher risk aversion may diversify their investment portfolios with gold. In contrast, investors with lower risk aversion 
can diversify their portfolios using BTC and expect higher returns. Similar conclusions were obtained by Okorie (2020), who examined the diversification possibilities of BTC, as well as shares from the S\&P500 stock index in 2016-2018. He confirmed that BTC is a profitable investment instrument, and also allows for a good diversification of equity portfolios.

Stensås, Nygaard, Kyaw and Treepongkaruna (2019), based on the analysis of investments in the currencies of BRICS countries (Brazil, Russia, India, China, and South Africa) and in precious metals in 2011-2018, noticed that BTC is particularly effective in the process of risk diversification of precious metal wallets. However, BTC does not contribute to lowering the risk in developing countries' currency portfolios. Garcia-Jorcano and Benito (2020) showed that in 2011-2019, BTC was an effective tool for diversifying investment portfolios containing shares of companies belonging to the following indices: S\&P500, STOXX50 (European Union), NIKKEI (Japan), CSI300 (Shanghai) and HSI (Hong Kong). Similar diversification properties of BTC in 2011-2016 were confirmed by Kang, Yoon and Bekiros (2020). They showed that the daily rates of return from BTC and the S\&P500 stock index, US treasury bonds and gold were negatively correlated with each other. In addition, they showed that investing in BTC not only reduces risk but also improves the efficiency of capital allocation. Qarni and Gulzar (2021) also confirmed BTC diversification properties with respect to currency portfolios consisting of the US dollar, Australian dollar, Canadian dollar, euro, British pound and Japanese yen.

Wang, Zhang, and Shen (2019) tested the two investment functions of BTC, i.e. diversifying stock portfolios and long-term storage of value. The study found that BTC had low diversification properties against the portfolio of stocks from 30 countries. Then again, long-term investment in this cryptocurrency was profitable. This allows to conclude that cryptocurrencies can serve as safe-haven investments. Hong (2017) also stated that in addition to its diversification properties, BTC could be an alternative investment tool.

Alternatively, Majdoub, Sassi and Bejaoui (2021), based on the analysis of daily quotations of BTC and prices of platinum, gold, silver, copper and wheat in 2013-2018, concluded that the disturbances in the BTC market could have had an impact on the level of prices on commodity exchanges. They found no possibility of an opposite effect, i.e. the transfer of disturbances from commodity exchanges to the BTC market. However, they confirmed that sudden changes in the trend of price formation in one of the analyzed markets could potentially trigger equally strong changes in trends in the other market. Baur, Lee and Hong (2018) found that BTC is currently more used as a speculative investment vehicle than global currency. This rule was confirmed by Aslanidis, Bariviera and Martínez-Ibáñez (2019). Additionally, they stated that BTC is not yet capable of performing the function of storing value, which can be achieved with the use of standard global currencies. Conversely, Gronwald (2019), analyzing the changes in BTC quotations in 2011-2019, stated that it can be used as a profitable investment tool, however, characterized by a high risk, the source of which is the significant sensitivity of BTC to external disturbances.

One of the few studies on the efficiency of investments in cryptocurrencies is the analysis by Wyderka and Saganowski (2018). Based on the comparison of the efficiency of investments in BTC and the efficiency of investments on the Polish stock market, they indicated that BTC is a more profitable instrument than the shares of Polish listed companies. How- 
ever, the performance of investment in BTC is not stable. Using the measures of standard deviation and the coefficient of variation of the rates of return, they did not find out which of the investments was exposed to the higher risk. Michalczyk (2018), while examining the relationship between the level of profitability and risk in investments in cryptocurrencies with the highest capitalization, stated that the risk of investing in all cryptocurrencies is high, while the level of expected income varies significantly.

\section{The global macroeconomic situation}

The situation of the major economies in 2011-2020 was significantly diversified (Table 1). Its condition in the first years of the decade was shaped by the negative effects of the global financial crisis of 2007-2009. In the EU countries, an important event for the state of the economy was the crisis resulting from excessive indebtedness of some euro area countries in 2011-2013. In turn, the slowdown in the growth rate of the Chinese economy had a great impact on the country's macroeconomic situation and also negatively affected the state of the economy and financial markets around the world. Another global macroeconomic factor was the outbreak of the COVID-19 pandemic in 2020 and the need to freeze the economy around the world for several weeks or months, which broke the dynamics of GDP growth and quotations on all financial markets.

Table 1. GDP growth of major world economies in 2011-2020 (\%)

\begin{tabular}{|l|l|l|l|l|l|l|l|l|l|l|}
\hline \multicolumn{1}{|c|}{ Country } & \multicolumn{1}{c}{2011} & \multicolumn{1}{c}{2012} & 2013 & 2014 & 2015 & 2016 & 2017 & 2018 & 2019 & 2020 \\
\hline France & 2.7 & 1.9 & -0.2 & 1.1 & 1.3 & 1.6 & 2.1 & 2.8 & 1.9 & -7.2 \\
\hline Germany & 3.5 & 2.2 & 0.2 & 1.9 & 1.8 & 1.5 & 2.1 & 3.1 & 0.8 & -4.1 \\
\hline Great Britain & 1.5 & 1.8 & 1.9 & 2.8 & 2.5 & 2.2 & 1.9 & 1.6 & 1.4 & -6.5 \\
\hline China & 10.2 & 8.5 & 8.6 & 7.8 & 7.4 & 7.1 & 7.4 & 7.2 & 6.8 & 2.1 \\
\hline Japan & -0.8 & 1.0 & 0.1 & 3.5 & 0.1 & 1.6 & 1.2 & 2.0 & 0.2 & -4.5 \\
\hline USA & 1.8 & 2.0 & 1.7 & 2.0 & 2.9 & 2.0 & 2.1 & 2.7 & 2.2 & -3.2 \\
\hline Euro area & 1.9 & 0.9 & 0.8 & 2.2 & 1.7 & 3.1 & 2.9 & 0.4 & -4.1 & -3.8 \\
\hline EU & 2.2 & 0.8 & 1.1 & 1.8 & 2.2 & 2.4 & 2.9 & 3.1 & 1.8 & -4.8 \\
\hline
\end{tabular}

S o u r c e: Authors' own elaboration based on Thomson Reuters data (Reuters.com, 2021).

The assistance activities of central banks and public authorities significantly changed the current vision of the financial system. High public debt has consolidated in the public finances of most countries of the world, and the reference interest rates of central banks dropped to the level of $0 \%$. On the one hand, these activities contributed to economic growth and an increase in share prices on capital markets. On the other hand, they permanently lowered the interest rate on debt instruments and, as a consequence, lowered their investment attractiveness. This resulted, inter alia, in shifting some investment capital from the bond market to the stock market and the cryptocurrency market. As a result of central banks' actions, the level of long-term interest rates, represented by the interest rate on 10-year treasury bonds, had a downward trend, reaching in some countries the negative values in the last years of the decade (Table 2). 
Table 2. The level of long-term interest rates

\begin{tabular}{|l|c|c|c|c|c|c|c|c|c|c|}
\hline \multicolumn{1}{|c|}{ Country } & 2011 & 2012 & 2013 & 2014 & 2015 & 2016 & 2017 & 2018 & 2019 & 2020 \\
\hline France & 3.01 & 2.44 & 2.41 & 0.90 & 0.99 & 0.68 & 0.79 & 0.71 & -0.02 & -0.34 \\
\hline Germany & 1.95 & 1.31 & 1.94 & 0.50 & 0.63 & 0.21 & 0.42 & 0.21 & -0.25 & -0.58 \\
\hline Great Britain & 1.98 & 2.12 & 3.09 & 1.72 & 1.93 & 1.34 & 1.20 & 1.28 & 0.75 & 0.20 \\
\hline China & 3.55 & 3.53 & 4.57 & 3.65 & 2.84 & 3.06 & 3.92 & 3.15 & 3.16 & 3.18 \\
\hline Japan & 1.35 & 1.00 & 0.72 & 0.62 & 0.58 & 0.38 & 0.19 & 0.16 & 0.04 & -0.05 \\
\hline USA & 1.80 & 1.18 & 3.07 & 2.26 & 2.27 & 2.46 & 2.41 & 2.66 & 1.79 & 0.91 \\
\hline
\end{tabular}

S o u r c e: Authors' own elaboration based on Thomson Reuters data (Reuters.com, 2021).

The environment of low and ultra-low interest rates persisting since the beginning of the decade was conducive to the increase in demand for cryptocurrencies, mainly BTC. During this time, the prices of individual cryptocurrencies increased several dozen or even several hundred times, while the quotations of short-term debt instruments clearly decreased.
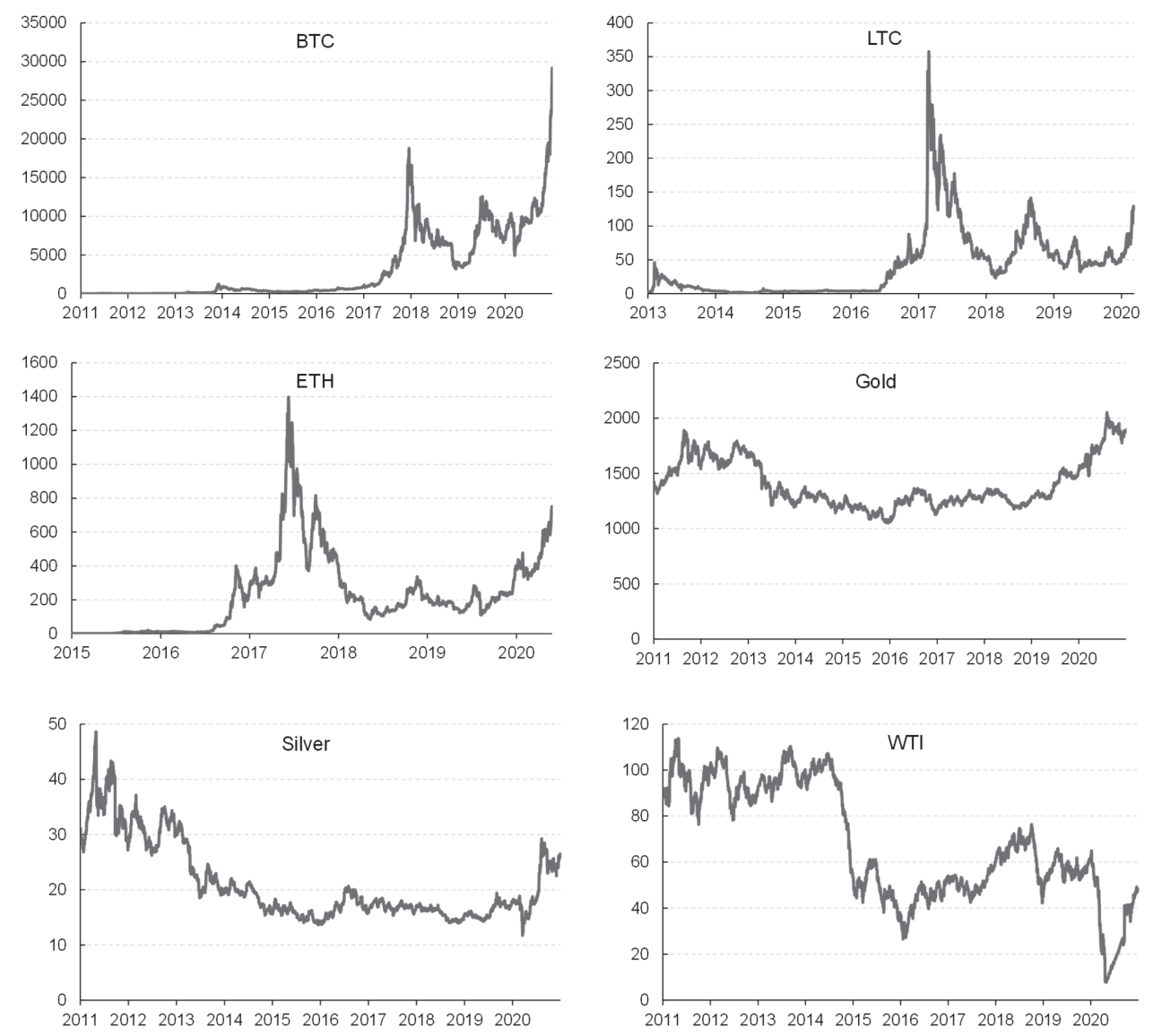

Figure 1. Quotations of selected investment instruments in 2011-2020

S o u r c e: Authors' own elaboration based on Thomson Reuters data (Reuters.com, 2021). 
The quotations of cryptocurrencies and goods on the commodity markets analyzed in the study took variable values. In the course of changes in cryptocurrency quotations, several periods with their dynamic increases and decreases can be distinguished. In the case of cryptocurrencies, these periods were in 2017-2018 and 2019. It is characteristic that the outbreak of the COVID-19 pandemic in March 2020 only temporarily weakened the strong upward trends in the quotations of most cryptocurrencies. In the case of commodities, the initial rise in prices of all goods related to the improved economic situation as a result of recovery from the GFC programmes was halted by the effects of the outbreak of the public finance crisis in the euro area countries. The weakening of the growth rate of the Chinese economy in the middle of the decade further lowered the prices of gold, silver and WTI. Following the recovery in commodities markets, the crisis triggered by the COVID-19 pandemic has plunged commodity prices again, albeit only in the short term.

\section{Materials and methods}

In the first stage of the research, daily logarithmic rates of return on investments in cryptocurrencies and selected commodities were calculated according to the following formula:

$$
r_{p t}=\ln \left(V_{p t}\right)-\ln \left(V_{p t-1}\right)=\ln \left(\frac{V_{p t}}{V_{p t-1}}\right)
$$

where: $\ln$ is the natural logarithm, $V_{p t}$ and $V_{p t-1}$ respectively, the value of the $p$ instrument on $t$ and $t-1$. In the next stage, the risk level of investments in selected instruments was estimated. Taking into account the methods used in previous studies, including Rehman (2020), Liu (2019), Wyderka and Saganowski (2018), the following measures were selected for risk assessment: standard deviation (SD) and semi-standard deviation (SE) of daily rates of return calculated according to the following formulas:

$$
\begin{aligned}
& S D=\sqrt{\frac{1}{n-1} \sum_{t=1}^{n}\left[r_{p t}-\overline{r_{p}}\right]^{2}} \\
& S E=\sqrt{\frac{1}{n-1} \sum_{t=1}^{n}\left[\left(r_{p t}-\overline{r_{p}}\right)^{-}\right]^{2}}
\end{aligned}
$$

where: $r_{p t}, \overline{r_{p}}$ denote, respectively, the daily rate of return on investment in the $p$ instrument on day $t$ and the average for the given period of the daily rates of return, $n$ - number of days in the analyzed period. The sign "--" indicates that only those cases are considered for the purpose of determining the standard deviation where $r_{p t}$ is less than $\overline{r_{p}}$. The rationale for adopting an asymmetric risk rating system is that investors only find it unfavourable when the portfolio's actual rate of return is lower than its average value.

Taking into account the research (Damianov and Elsayed, 2020; Rehman, 2020; Liu, 2019), the efficiency of investments in cryptocurrencies and selected instruments was calculated using the Sharpe ratio (WS) and the Sortino ratio (S) using the following formulas, respectively:

$$
\begin{aligned}
& W S=\frac{r_{p}-r_{f}}{S D} \\
& S=\frac{\overline{r_{p}}-m}{S E}
\end{aligned}
$$


where in addition to the previously explained variables, $r_{f}$ denotes the average rate of return for risk-free instrument over the period, and respectively. In the study, 3-month US Treasury bills (US 3M T-bill) were adopted as a risk-free instrument. The inventors of the Sortino ratio suggest that the minimum acceptable rate of return $m$ should be $0 \%$ or the rate of return from the market portfolio, e.g. represented by a selected stock index (Sortino and Price, 1994). In the study, the value of $0 \%$ was assumed for the variable $m$.

\section{Results and discussion}

In the first stage of the calculations, the daily rates of return on investment in individual instruments were calculated. The values of daily rates of return were volatile for all instruments, with investments in cryptocurrencies being the most volatile. They brought both the highest and the lowest average daily rates of return $(2.99 \%$ - LTC in $2013 ;-0.59 \%$ - LTC in 2014). The average values of daily rates of return throughout the analyzed period obtained from investments in cryptocurrencies ranged from $0.31 \%$ (BTC) to $0.43 \%$ (LTC). These values were many times higher than in the case of goods whose average for the entire period ranged from $-0.017 \%$ (Oil WTI) to $0.008 \%$ (Gold). 2016 and 2019 were the periods of growth for all analyzed instruments, and the periods of declines in 2014 and 2018.

In the next stage of the research, the values of investment risk measures were determined: standard deviation (SD) and semi-standard deviation (SE) of daily rates of return. The obtained results indicate that investments in cryptocurrencies are characterized by a much higher level of risk than investments in goods. In the case of cryptocurrencies, the highest levels of risk were recorded in the first years of their presence on the market and the period of dynamic growth and subsequent decline in their prices in 2017 and 2018. In the case of gold and silver, the highest risk was recorded in the first years after the GFC and the COVID-19 pandemic period. In turn, the risk on the WTI market depended on the economic situation in the largest economies, including China. For this reason, the risk was the highest in 2011, 2015, 2016 and 2020. The mean values of the SD indicator for cryptocurrencies for the entire period ranged from $4.50 \%$ (BTC) to $7.42 \%$ (LTC), while for goods from $0.83 \%$ (Gold) to $1.95 \%$ (WTI). Also, the risk measured by the SE indicator turned out to be the highest in the case of investments in cryptocurrencies (from $3.00 \%$, BTC, to $4.22 \%$, LTC) and many times lower in the case of investments in goods (from $0.59 \%$ (Gold) to $1.44 \%$ (WTI)).

The last stage of the calculations was to estimate the investment efficiency using the Sharpe ratio and the Sortino ratio, in the version for $m=0 \%$ (Table 3 ).

Table 3. Investment efficiency measured by Sharpe and Sortino ratios in 2011-2020 (\%)

\begin{tabular}{|l|c|c|c|c|c|c|c|c|c|c|c|}
\hline Country & 2011 & 2012 & 2013 & 2014 & 2015 & 2016 & 2017 & 2018 & 2019 & 2020 \\
\hline \multicolumn{8}{|c|}{ Sharpe index } \\
\hline BTC & 8.76 & 8.71 & 14.96 & -6.69 & 2.37 & 9.18 & 15.89 & -9.00 & 4.89 & 10.43 \\
\hline LTC & & & 14.53 & -10.19 & 1.04 & 2.16 & 13.37 & -9.89 & 1.78 & 6.00 \\
\hline ETH & & & & & 1.46 & 8.64 & 17.74 & -8.41 & -0.19 & 9.88 \\
\hline Gold & 2.42 & 2.19 & -7.76 & -0.55 & -3.87 & 2.61 & 6.47 & -1.11 & 7.91 & 5.32 \\
\hline Silver & -1.12 & 1.37 & -6.98 & -5.08 & -2.36 & 2.80 & 2.01 & -2.91 & 3.85 & 4.37 \\
\hline WTI & 1.23 & -1.53 & 2.08 & -13.46 & -4.40 & 4.26 & 2.39 & -4.92 & 5.19 & -1.32 \\
\hline
\end{tabular}




\begin{tabular}{|l|c|c|c|c|c|c|c|c|c|c|}
\hline \multicolumn{10}{|c|}{ Sortino index } \\
\hline BTC & 13.82 & 13.04 & 24.11 & -9.45 & 3.12 & 14.83 & 26.11 & -11.07 & 7.78 & 15.13 \\
\hline LTC & & & 27.59 & -8.96 & 1.43 & 2.96 & 25.76 & -13.10 & 2.77 & 8.43 \\
\hline ETH & & & & & 3.81 & 13.71 & 31.53 & -10.87 & -0.26 & 13.12 \\
\hline Gold & 3.14 & 3.03 & -9.56 & -0.84 & -5.42 & 3.95 & 9.60 & -1.54 & 12.18 & 7.61 \\
\hline Silver & -1.39 & 1.91 & -9.02 & -6.93 & -3.25 & 3.81 & 2.73 & -3.95 & 5.61 & 6.03 \\
\hline WTI & 1.67 & -2.15 & 2.89 & -15.78 & -6.14 & 6.52 & 3.24 & -6.35 & 7.71 & -1.69 \\
\hline
\end{tabular}

S o u r c e: Author's own elaboration based on Thomson Reuters data (Reuters.com, 2021).

The results of the calculations indicate that in the case of investments in cryptocurrencies, despite the high level of risk especially observed in the first years of their operation on the market, they obtained high efficiency values. Other periods of high efficiency were the years 2017 and 2020, i.e. periods of strong increases in cryptocurrency prices (Figure 1). In turn, the lowest efficiency was recorded in the years immediately following the growth periods, i.e. 2014 and 2018. A similar cyclicality can be noticed in the case of efficiency of investments in commodities. After the increase in efficiency in 2012, there was a long-term decline, which ended in 2016, when the economic situation improved, and the prices of these goods started to rise. The situation on the WTI oil market was much more volatile, which resulted in frequent changes in the trend in the value of efficiency of investments in this commodity. In the case of WTI, the year 2016 was the turning point, characterized by a strong rebound and improvement in efficiency.
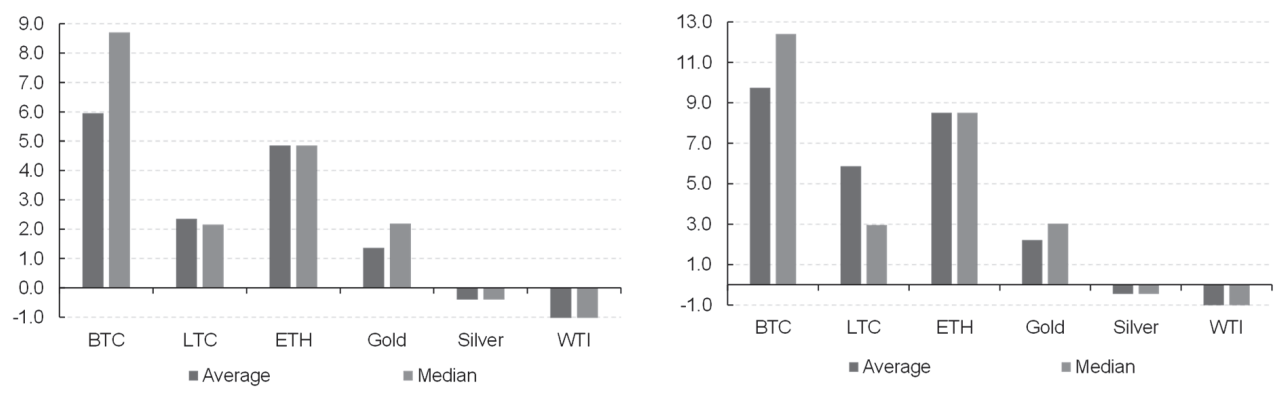

Figure 2. Average and median investment efficiency in 2011-2020 (\%) measured by the Sharpe ratio (left panel) and the Sortino ratio (right panel)

S o u r c e: Author's own elaboration based on Thomson Reuters data (Reuters.com, 2021).

The average for the entire period of the efficiency of investments in cryptocurrencies turned out to be higher than the efficiency of investments on global commodity markets which confirms the hypothesis that investments in cryptocurrencies in 2011-2020 were more effective than in commodity market instruments. Investments in BTC and ETH turned out to be the most effective - both when measured by the Sharpe ratio and the Sortino ratio. Such a distribution of efficiency could have been significantly influenced by the high market capitalization of these cryptocurrencies. At the end of 2020, BTC and ETH had the highest market shares of $70 \%$ and $11 \%$, respectively. 
Investments in gold turned out to be the most effective investments in the commodity market. Its high and growing quotations, initiated in 2016, contributed to the fact that the investment efficiency was particularly high. In 2019 it was the highest among the analyzed instruments. Then again, investments in silver and WTI, on average, achieved negative efficiency, both measured by the Sharpe and Sortino ratios. Their weak results were significantly influenced by the achievement of particularly low efficiencies in 2013, 2014 and 2018.

\section{Conclusions}

Cryptocurrencies have increased their importance in the economy and have become an essential element of the global financial system. In addition to the payment function, they are increasingly used as an investment tool. They serve as diversifiers of investment portfolios, including composed of precious metals, global currencies as well as equities of international companies. A new feature of cryptocurrencies is their ability of long-term storing value.

The study confirms that investing in cryptocurrencies (BTC, LTC and ETH) brings much higher rates of return than investing in commodities. This means that, despite the high level of risk, investments in cryptocurrencies are much more efficient than investments in commodities. The efficiency of investments in cryptocurrencies is of cyclical nature, which is related to frequent changes in the trends in their quotations.

Unlike commodities, the efficiency of cryptocurrency investments is not so closely related to the state of the global economy. Among the commodities, the strongest correlation is found with the level of investment efficiency in WTI, which, according to the World Bank data, changes quite in line with the changes in GDP in the USA and the European Union.

High profitability, however, caused that the efficiency of investments in cryptocurrencies in 2011-2020 was, on average, higher than the efficiency of investments in analyzed commodities. The high-capitalization cryptocurrencies, i.e. BTC and ETH, were found to be the most efficient investment tools.

The persistence of the ultra-low interest rate environment could have had a significant impact on the high efficiency of investments in cryptocurrencies. They lowered the profitability of investments in debt securities, primarily Treasury bonds, and contributed to the transfer of investment capital, among others, to the cryptocurrency market. It is characteristic that despite the deep crisis caused by the COVID-19 pandemic, the efficiency of investments in cryptocurrencies reached one of the highest levels.

\section{References}

Aslanidis, N., Bariviera, A. F., Martínez-Ibáñez, O. (2019). An analysis of cryptocurrencies conditional cross correlations. Finance Research Letters, 31, 130-137. DOI: 10.1016/j.frl.2019.04.019.

Baur, D. G., Lee, A. D., Hong, K. (2018). Bitcoin: medium of exchange or speculative assets? Journal of International Financial Markets, Institutions and Money, 54, 177-189. DOI: 10.1016/j.intfin.2017.12.004.

Damianov, D. S., Elsayed, A. H. (2020). Does Bitcoin add value to global industry portfolios? Economics Letters, 19(C). DOI: 10.1016/j.econlet.2019.108935. 
García-Jorcanoa, L., Benito, S. (2020). Studying the properties of the Bitcoin as a diversifying and hedging asset through a copula analysis: Constant and time-varying. Research in International Business and Finance, 54(C). DOI: 10.1016/j.ribaf.2020.101300.

Gronwald, M. (2019). Is Bitcoin a commodity? On price jumps, demand shocks, and certainty of supply. Journal of International Money and Finance, 97, 86-92. DOI:10.1016/j.jimonfin.2019.06.006.

Hong, K. (2017). Bitcoin as an alternative investment vehicle. Information Technology and Management, 18, 265-275. DOI: 10.1007/s10799-016-0264-6.

Hung, P. K., Ly, S., Lu, R., Hoang, T. H. V., Wong, W. K. (2021). Is Bitcoin a better portfolio diversifier than gold? A copula and sectoral analysis for China. International Review of Financial Analysis, 74. DOI: 10.1016/j.irfa.2021.101674.

Kang, S. H., Yoon, S. M., Bekiros, S., Uddin, G. S. (2020). Bitcoin as hedge or safe haven: Evidence from stock, currency, bond and derivatives markets. Computational Economics, 56, 529-545. DOI:10.1007/ s10614-019-09935-6.

Liu, W. (2019). Portfolio diversification across cryptocurrencies. Finance Research Letters, 29, 200-205. DOI: $10.1016 /$ j.frl.2018.07.010.

Majdoub, J., Sassi, S. B., Bejaoui, A. (2021). Can fiat currencies really hedge Bitcoin? Evidence from dynamic short-term perspective. Decisions in Economics and Finance. DOI: 10.1007/s10203-020-00314-7.

Michalczyk, W. (2018). Główne zależności pomiędzy poziomem dochodu, ryzyka i rozpowszechnienia najważniejszych kryptowalut. Studia Ekonomiczne - Zeszyty Naukowe Uniwersytetu Ekonomicznego w Katowicach, 372, 71-83.

Okorie, D. I. (2020). Did China's ICO ban alter the Bitcoin market? International Review of Economics \& Finance, 69, 977-993. DOI: 10.1016/j.iref.2020.05.016.

Qarni, M. O., Gulzar, S. (2021). Portfolio diversification benefits of alternative currency investment in Bitcoin and foreign exchange markets. Financial Innovation, 7. DOI: 10.1186/s40854-021-00233-5.

Rehman, M. U. (2020). Do Bitcoin and precious metals do any good together? An extreme dependence and risk spillover analysis. Resources Policy, 68, 1-16. DOI: 10.1016/j.resourpol.2020.101737.

Reuters.com. (2021). Global Market Data [online, accessed: 2021-06-02]. Retrieved from: https://www.reuters.com/markets/global-market-data.

Sortino, F., Price, L. (1994). Performance measurement in a downside risk framework. Journal of Investing, $30,1519-1533$.

Stensås, A., Nygaard, M. F., Kyaw, K., Treepongkaruna, S. (2019). Can Bitcoin be a diversifier, hedge or safe haven tool? Cogent Economics \& Finance, 7(1), 1-21. DOI: 10.1080/23322 039.2019.1593072.

UKNF. (2021). Ostrzeżenie Urzędu KNF o ryzykach zwiazanych z nabywaniem oraz z obrotem kryptoaktywami [online, accessed: 2021-06-25]. Retrieved from: https://www.knf.gov.pl/knf/pl/komponenty/ img/Ostrzezenie_UKNF_o_ryzykach_zwiazanych_z_nabywaniem_oraz_z_obrotem_kryptoaktywami_72241.pdf.

Wang, P., Ž Zhang, W., Li, X., Shen, D. (2019). Is cryptocurrency a hedge or a safe haven for international indices? A comprehensive and dynamic perspective. Finance Research Letters, 31(C), 1-18. DOI: 10.1016/j. frl.2019.04.031.

Wyderka, D., Saganowski, T. (2018). Efektywność inwestycji na rynku kryptowalut i inwestycji na rynku giełdowym - ujęcie porównawcze. Finanse i Prawo Finansowe, 3(19), 67-77. DOI: 10.18778/2391$-6478.3 .19 .06$. 


\title{
Inwestycje na rynku kryptowalut czy giełdzie towarowej. Co jest bardziej efektywne?
}

\begin{abstract}
Abstrakt: Kryptowaluty stały się istotnym elementem gloluty były obarczone najwyższym ryzykiem, ale jednocześbalnego systemu finansowego, a w ostatnich latach także częstym narzędziem inwestycyjnym. Celem opracowania jest sprawdzenie czy inwestycje w kryptowaluty są bardziej efektywne niż w towary na giełdach towarowych. Badanie przeprowadzono, bazując na dziennych notowaniach analizowanych instrumentów w latach 2011-2020. Poziom efektywności inwestycji oszacowano wskaźnikami Sharpe'a i Sortino. Wyniki badań pozwoliły na stwierdzenie, że średnio w całym badanym okresie inwestycje w kryptowanie uzyskiwały najwyższe dzienne stopy zwrotu. Dzięki temu były one znacznie bardziej efektywnymi narzędziami inwestycyjnymi niż złoto, srebro i WTI. Przewaga kryptowalut mogła wynikać z długotrwałego utrzymywania się ultraniskich stóp procentowych i obniżenia atrakcyjności inwestycji w dłużne papiery wartościowe. Bitcoin i etherum, posiadające największe udziały w kapitalizacji rynku kryptowalut, okazały się najbardziej efektywnymi narzędziami inwestycyjnymi.
\end{abstract}

Słowa kluczowe: kryptowaluty, inwestycje, giełdy towarowe, efektywność inwestycji 